\title{
Investigation on Factors Associated with Back Sore in Working Donkeys in Ada'a District, Central Oromia, Ethiopia
}

\section{Bedaso Kebede Kassaye, DVM}

Veterinary Drug and Animal Feed Administration and Control Authority, Ministry of Agriculture, Addis Ababa, Ethiopia.

"Corresponding author: Bedaso Kebede Kassaye, DVM, Veterinary Drug and Animal Feed Administration and Control Authority, Ministry of Agriculture, Addis Ababa, Ethiopia, Tel: 0913136824; E-mail: Kebede.bedaso@yahoo.com

Rec date: Aug 03, 2015; Acc date: Sep 07, 2015; Pub date: Sep 09, 2015

Copyright: () 2015 Kassaye. This is an open-access article distributed under the terms of the Creative Commons Attribution License, which permits unrestricted use, distribution, and reproduction in any medium, provided the original author and source are credited.

\begin{abstract}
The cross-sectional study was carried out from November 2009 to April 2010 to investigate factors associated with back sore in working donkeys in Ada'a district, central Oromia, Ethiopia. A total of three hundred eighty five (385) working donkeys with back sore were randomly selected and examined for risk factors back sore. The study revealed that the degree of sore was statistically associated $(P<0.05)$ with sex, cause and age but insignificantly associated $(P>0.05)$ with body condition score. Old age donkeys were extremely vulnerable $256(66.5 \%)$ to the back sore, the highest frequency of mild degree of back sore $215(55.8 \%)$ and medium body condition score donkeys 218 $(56.6 \%)$ was observed. The location of the back sore was significantly associated $(\mathrm{P}<0.05)$ with body conditions but not associated $(\mathrm{P}>0.05)$ with sex, age and cause of the back sore. In the study improper harnessing and padding $198(51.4 \%)$ followed by overloading and overworking $184(47.8 \%)$ were the most cause of donkeys back sore. Type of back sore showed a significant $(\mathrm{P}<0.05)$ variation in donkeys with different risk factors sex, age, body condition score and cause of sore and erosion 169 (43.9\%) was the most frequent followed by laceration $110(28.6 \%)$ in the study area. The current study revealed that there is no variation $(P>0.05)$ in the treatment offered to donkeys with different risk factors sex, age, cause of sore and body condition score. Majority of donkeys with back sore $339(88 \%)$ were not gained any treatment. This infers that back sore is the major health and welfare problems of donkeys that compromise performances of working donkeys of the study area.
\end{abstract}

Keywords: Back sore; Risk factors; Donkeys; Ada'a district

\section{Introduction}

The world and Africa's donkey population is about 44 million and 13.7 million respectively. In developing countries $95 \%$ of donkeys are found and the rest in developed countries [1]. In the developing world the highest donkey population is found in central Asia, North and East Africa [2]. Donkeys in developing countries are kept mainly for work [3]. Donkeys play an important role in rural communities by providing power and transport at a low cost. They are also used for various agricultural operations such as ploughing, planting, and weeding and provide the much needed transport in rural areas for activities such as carrying building materials, agricultural products, people and fetching water [4].

Ethiopia possess about 5.2 million of donkeys which is the second largest donkey population in the world next to China and stands first in Africa with over forty percent of Africa's donkey population [5]. In Ethiopia there is one equine for every four people in agricultural sector. Donkeys have been a part of farming system as animal power in areas with scarcity of oxen supply for ploughing in the highland part of the country road [6]. The low level of development of the transport system and the rough terrain of the country make donkeys the vulnerable, appropriate and affordable pack animal under the small holder farming system [7]. Donkeys are the most suitable means of transportation in Ethiopia due to the mountainous and rugged terrain landscape [8]. Despite their great importance donkeys have been suffering from overwork and malnutrition as most of their owners are poor and resource limited and depend on these animals for their livelihood [9]. In household without donkeys the women take the responsibilities of doing heavy work [10]. Donkeys are often described as sturdy animals, hence are exposed to a variety of diseases and many other adverse conditions [11].

A poorly designed or ill-fitted harness can cause inefficient transfer of power from the donkeys to the implement and cause fatigue, discomfort or injury the donkey [4]. Donkeys are usually much more affected than horses and mules because of widely prevailing opinion that they are tolerant to harsh condition, and carry heavy load over long distances for long period of time and travel as far as $70 \mathrm{~km} /$ day while carrying an average weight load of $150 \mathrm{~kg}$. These are the major cause of injuries on the back of donkeys due to overloading and overweight. Traditionally constructed wooden or iron-made saddles are constantly put on the back and strongly tied to the body by plastic rope which causes persistent irritation and injuries [12]. Back sore is a common and widely distributed problem of health and welfare of working donkeys in all parts of Ethiopia and there is scarcity of information on the economic importance, proportion and potential risk factors in Ethiopia.

Therefore, the main objective of this paper is to investigate the factors associated with back sore in working donkeys in Ada'a district, central Oromia, Ethiopia.

\section{Materials and Methods}

\section{Study area}

The study was conducted from November, 2009 to April, 2010 in Ada'a district, central Oromia. Bishoftu is the main town of Ada'a district which is $47 \mathrm{~km}$ South East of Addis Ababa capital city of 
Citation: Kassaye BK. (2015) Investigation on Factors Associated with Back Sore in Working Donkeys in Ada'a District, Central Oromia,

Page 2 of 6

Ethiopia. Bishoftu is geographically located at $90 \mathrm{~N}$ and $400 \mathrm{E}$ and an altitude of $1900 \mathrm{~m}$ above sea level. The rainfall is bimodal. The area receives an annual rainfall of $850 \mathrm{~mm}$ with a maximum and minimum range of temperature $30.70^{\circ} \mathrm{C}$ and $8.50^{\circ} \mathrm{C}$, respectively. The average relative humidity is $61.3 \%$ [13]. The donkey population of the district is 46,222 [14]. Donkeys are primarily used for carrying water, materials for sale to the market, fire wood, farm products, construction materials as well as straw in the study area.

\section{Sample determination}

As there is no previous studies on the back sore of working donkeys in the Ada'a district the sample size for this study was calculated by using $95 \%$ confidence level, $5 \%$ precision and $50 \%$ expected prevalence according to Thrusfield [15] and 385 of working donkeys with back sore was studied.

\section{Study animals and design}

The study animals were specifically working donkeys with back sore in Ada'a district. The cross sectional study on a total of 385 donkeys with back sore was randomly selected from donkeys with back sore visited the stationary and mobile clinic of the Donkey Health and Welfare Clinic Project for the deworming programme. Each randomly selected donkey with back sore was examined for only one location of back sore on donkey. Clinical examination of donkeys with the back sore was performed regarding to sex, age and body condition. Information about back sore on each affected donkey that include cause, location, type, degree of sore and treatment were collected. The age of the selected donkeys having back sore was determined by dentition according to Crane [16] and body condition was scored poor, medium and good as described by Svendsen [11]. Donkeys with back sore were grouped into three age categories. Donkeys with back sore under two years of age were classed as young $(n=2)$, those in range of two to ten years were classed as adult $(n=127)$ and those beyond ten years were classed as old $(n=256)$. These age classes were based on age of first work, productive age and the life span of Ethiopian donkeys $[17,18]$.

\section{Data analysis}

Data collected was entered into computer using excel spread sheet. It was analyzed using statistical software SPSS for windows version 15.0. Descriptive statistics and Chi-square were used. The confidence level was set at $95 \%$ and $\mathrm{P}<0.05$ was set for level of significance.

\section{Results}

Study on donkeys with back sore visited stationary and mobile clinic of Donkey Health and Welfare Project was revealed that the mild degree of back sore was the higher in all risk factors except in unknown cause and degree of back sore was statistically significant $(\mathrm{P}<0.05)$ with cause, sex and age. It was insignificantly associated $(\mathrm{P}>0.05)$ with the body condition score. The major cause of donkey's back sore was improper harnessing and padding 198(51.4\%) followed by overloading and working $184(47.8 \%)$ (Table 1$)$. The study showed that back sore on the thoracic 211(54.8\%) was higher in all risk factors than other location of sore on back of donkeys and differently associated $(\mathrm{P}<0.05)$ with the risk factors (Table 2$)$. The study revealed that erosion $169(43.9 \%)$ was the most common type of wound observed on the back of donkey and significantly associated $(\mathrm{P}<0.05)$ with risk factors (Table 3).The study cleanly showed that majority of the owners at the study area rarely treated their donkeys for back sore. Among types of treatment given traditional treatment $30(7.8 \%)$ was redundantly rendered than modern treatment $16(4.2 \%)$ offered and insignificantly associated $(\mathrm{P}<0.05)($ Table 4$)$.

\begin{tabular}{|c|c|c|c|c|c|c|c|c|}
\hline \multicolumn{2}{|c|}{ Risk factors } & \multicolumn{4}{|c|}{ Degree of back sore } & \multirow[t]{2}{*}{$\mathrm{X}^{2}$ value } & \multirow[t]{2}{*}{ Df } & \multirow[t]{2}{*}{ P-value } \\
\hline Sex & Jenny & $131(34 \%)$ & $14(3.6 \%)$ & $58(15.1 \%)$ & $203(52.7 \%)$ & & & \\
\hline & Jack & $84(21.8 \%)$ & $23(6 \%)$ & $75(19.5 \%)$ & $182(47.3 \%)$ & 13.531 & 2 & 0.001 \\
\hline \multicolumn{2}{|l|}{ Total } & $215(55.8 \%)$ & $37(9.6 \%)$ & $133(43.6 \%)$ & $385(100 \%)$ & & & \\
\hline \multirow[t]{3}{*}{ Age } & Young & $2(0.5 \%)$ & 0 & 0 & $2(0.5 \%)$ & & & \\
\hline & Adult & $81(21 \%)$ & $15(3.9 \%)$ & $31(8.1 \%)$ & $127(33 \%)$ & 10.626 & 4 & 0.031 \\
\hline & Old & $132(34.3 \%)$ & $22(5.7 \%)$ & $102(26.5 \%)$ & $256(66.5 \%)$ & & & \\
\hline \multicolumn{2}{|l|}{ Total } & $215(55.8 \%)$ & $37(9.6 \%)$ & $133(34.6 \%)$ & $386(100 \%)$ & & & \\
\hline \multirow[t]{3}{*}{ BCS } & Poor & $57(14.8 \%)$ & $15(3.9 \%)$ & $48(12.5 \%)$ & $120(31.2 \%)$ & & & \\
\hline & Medium & $129(33.5 \%)$ & $15(3.9 \%)$ & $74(19.2 \%)$ & $218(56.6 \%)$ & 9.061 & 4 & 0.060 \\
\hline & Good & $29(7.5 \%)$ & $7(1.8 \%)$ & $11(2.9 \%)$ & $47(12.2 \%)$ & & & \\
\hline \multicolumn{2}{|l|}{ Total } & $215(55.8 \%)$ & $37(9.6 \%)$ & $133(34.6 \%)$ & $385(100 \%)$ & & & \\
\hline \multirow[t]{3}{*}{ Cause } & $\begin{array}{l}\text { Improper } \\
\text { harnessing and }\end{array}$ & $124(32.2 \%)$ & $20(5.2 \%)$ & $54(14 \%)$ & $198(51.4 \%)$ & & & \\
\hline & padding & $90(23.4 \%)$ & $17(4.4 \%)$ & $77(20 \%)$ & $184(47.8 \%)$ & & & \\
\hline & $\begin{array}{l}\text { Overloading } \\
\text { and working }\end{array}$ & $1(0.3 \%)$ & 0 & $2(0.5 \%)$ & $3(0.8 \%)$ & 41.734 & 14 & 0.000 \\
\hline
\end{tabular}


Citation: Kassaye BK. (2015) Investigation on Factors Associated with Back Sore in Working Donkeys in Ada'a District, Central Oromia, Ethiopia. J Veterinar Sci Technol 6: 256. doi:10.4172/2157-7579.1000256

Page 3 of 6

\begin{tabular}{|l|l|l|l|l|l|l|l|}
\hline & Unknown & & & & & & \\
\hline Total & & & $22(5.7 \%)$ & $133(34.5 \%)$ & $385(100 \%)$ & & \\
\hline & & $215(55.9 \%)$ & & & & & \\
\hline
\end{tabular}

Table 1: Risk factors for degree of back sore in donkeys. Jenny=Female Donkey, Jack=Male Donkey.

\begin{tabular}{|c|c|c|c|c|c|c|c|c|c|}
\hline \multicolumn{2}{|c|}{ Risk factors } & \multicolumn{5}{|c|}{ Location of sore on back } & \multirow{3}{*}{$\begin{array}{l}\mathbf{X}^{2} \\
\text { value } \\
4.125\end{array}$} & \multirow{3}{*}{$\begin{array}{l}\text { df } \\
8\end{array}$} & \multirow{3}{*}{$\begin{array}{l}\text { P-value } \\
0.846\end{array}$} \\
\hline & & \multirow{2}{*}{$\begin{array}{l}\text { Wither } \\
29(7.5 \%)\end{array}$} & \multirow{2}{*}{\begin{tabular}{|l|} 
Thoracic \\
$104(27 \%)$ \\
\end{tabular}} & \multirow{2}{*}{$\begin{array}{l}\text { Lumbar } \\
62(16.1 \%)\end{array}$} & \multirow{2}{*}{$\begin{array}{l}\text { Sacral } \\
8(2.1 \%)\end{array}$} & \multirow{2}{*}{$\begin{array}{l}\text { Total } \\
203(52.7 \%)\end{array}$} & & & \\
\hline Sex & Jenny & & & & & & & & \\
\hline & Jack & $23(6 \%)$ & $107(27.8 \%)$ & $47(12.2 \%)$ & $5(1.3 \%)$ & $182(47.3 \%)$ & & & \\
\hline & Total & $52(13.5 \%)$ & $211(54.8 \%)$ & $109(28.3 \%)$ & $13(3.4 \%)$ & $385(100)$ & & & \\
\hline \multirow{4}{*}{ Age } & Young & 0 & $1(0.3 \%)$ & $1(0.3 \%)$ & 0 & $2(0.6 \%)$ & & & \\
\hline & Adult & $17(4.4 \%)$ & $63(16.4 \%)$ & $38(9.9 \%)$ & $9(2.3 \%)$ & $127(33 \%)$ & 17.339 & 16 & 0.364 \\
\hline & Old & $35(9.1 \%)$ & $147(38.1 \%)$ & $70(18.2 \%)$ & $4(1 \%)$ & $256(66.4 \%)$ & & & \\
\hline & Total & $52(13.5 \%)$ & $211(54.8 \%)$ & $109(28.4 \%)$ & $13(3.3 \%)$ & $385(100 \%)$ & & & \\
\hline \multirow[t]{4}{*}{ BCS } & Poor & $8(2.1 \%)$ & $69(17.9 \%)$ & $41(10.6 \%)$ & $2(0.5 \%)$ & $120(31.1 \%)$ & & & \\
\hline & Medium & $32(8.3 \%)$ & $121(31.4 \%)$ & $57(14.8 \%)$ & $8(2.1 \%)$ & $218(56.6 \%)$ & 26.345 & 16 & 0.049 \\
\hline & Good & $12(3.1 \%)$ & $21(5.5 \%)$ & $11(2.9 \%)$ & $3(0.8 \%)$ & $47(12.3 \%)$ & & & \\
\hline & Total & $52(13.5 \%)$ & $211(54.8 \%)$ & $109(28.3 \%)$ & $13(3.4 \%)$ & $385(100 \%)$ & & & \\
\hline \multirow[t]{4}{*}{ Cause } & $\begin{array}{l}\text { Improper } \\
\text { and padding }\end{array}$ & $28(7.3 \%)$ & $102(26.5 \%)$ & $59(15.3 \%)$ & $9(2.3 \%)$ & $198(51.4 \%)$ & 72.585 & 56 & 0.067 \\
\hline & $\begin{array}{l}\text { Overloading } \\
\text { and working }\end{array}$ & $24(6.2 \%)$ & $107(27.8 \%)$ & $49(12.7 \%)$ & $4(1 \%)$ & $184(47.8 \%)$ & & & \\
\hline & Unknown & 0 & $2(0.5 \%)$ & $1(0.3 \%)$ & 0 & $3(0.8 \%)$ & & & \\
\hline & Total & $52(13.5 \%)$ & $211(54.8 \%)$ & $109(28.3 \%)$ & $13(3.3 \%)$ & $385(100 \%)$ & & 56 & 0.067 \\
\hline
\end{tabular}

Table 2: Risk factors with location of sore on donkeys back.

\begin{tabular}{|c|c|c|c|c|c|c|c|c|c|c|c|c|}
\hline \multicolumn{2}{|c|}{ Risk Factors } & \multicolumn{8}{|l|}{ Type of sore } & \multirow[t]{3}{*}{$\mathbf{X} 2$} & \multirow[t]{3}{*}{ df } & \multirow{3}{*}{$\begin{array}{l}\text { P- } \\
\text { value }\end{array}$} \\
\hline & & Laceration & Puncture & Erosion & Hematoma & $\begin{array}{l}\text { Swelling } \\
\text { and } \\
\text { Erosion }\end{array}$ & Incision & Burns & Total & & & \\
\hline \multirow[t]{3}{*}{ Sex } & Jenny & $49(12.7 \%)$ & 0 & $106(27.5 \%)$ & $5(1.3 \%)$ & $9(2.3 \%)$ & $1(0.3 \%)$ & $33(8.6 \%)$ & $203(52.7 \%)$ & & & \\
\hline & Jack & $61(15.8 \%)$ & $3(0.8 \%)$ & $63(16.4 \%)$ & $9(2.3 \%)$ & $9(2.3 \%)$ & $1(0.3 \%)$ & $36(9.4 \%)$ & $182(47.3 \%)$ & 15.424 & 6 & 0.017 \\
\hline & Total & $110(28.6 \%)$ & $3(0.8 \%)$ & $169(43.9 \%)$ & $14(3.6 \%)$ & $18(4.7 \%)$ & $2(0.5 \%)$ & $69(17.9 \%)$ & $385(100 \%)$ & & & \\
\hline \multirow[t]{4}{*}{ Age } & Young & 0 & 0 & $2(0.5 \%)$ & 0 & 0 & 0 & 0 & $2(0.5 \%)$ & & & \\
\hline & Adult & $26(6.8 \%)$ & $1(0.3 \%)$ & $62(16.1 \%)$ & $4(1 \%)$ & $9(2.3 \%)$ & $1(0.3 \%)$ & $24(6.2 \%)$ & $127(33 \%)$ & 11.060 & 12 & 0.524 \\
\hline & Old & $84(21.8 \%)$ & $2(0.5 \%)$ & $105(27.3 \%)$ & $10(2.6 \%)$ & $9(2.3 \%)$ & $1(0.3 \%)$ & $45(11.7 \%)$ & $256(66.5 \%)$ & & & \\
\hline & Total & $110(28.6 \%)$ & $3(0.8 \%)$ & $169(43.9 \%)$ & $14(3.6 \%)$ & $18(4.7 \%)$ & $2(0.5 \%)$ & $69(17.9 \%)$ & $385(100 \%)$ & & & \\
\hline
\end{tabular}


Citation: Kassaye BK. (2015) Investigation on Factors Associated with Back Sore in Working Donkeys in Ada'a District, Central Oromia,

Page 4 of 6

\begin{tabular}{|c|c|c|c|c|c|c|c|c|c|c|c|c|}
\hline \multirow[t]{4}{*}{ BCS } & Poor & $43(11.2 \%)$ & $2(0.5 \%)$ & $51(13.2 \%)$ & $4(1 \%)$ & $9(2.3 \%)$ & 0 & $11(2.9 \%)$ & $120(31.2 \%)$ & & & \\
\hline & Medium & $58(15.1 \%)$ & $1(0.3 \%)$ & $99(25.7 \%)$ & $6(1.6 \%)$ & $8(2.1 \%)$ & $1(0.3 \%)$ & $45(11.7 \%)$ & $218(56.6 \%)$ & 24.373 & 12 & 0.018 \\
\hline & Good & $9(2.3 \%)$ & 0 & $19(4.9 \%)$ & $4(1 \%)$ & $1(0.3 \%)$ & $1(0.3 \%)$ & $13(3.4 \%)$ & $47(12.2 \%)$ & & & \\
\hline & Total & $110(28.6 \%)$ & $3(0.8 \%)$ & $169(43 . \%)$ & $14(3.6 \%)$ & $18(4.7 \%)$ & $2(0.5 \%)$ & $69(17.9 \%)$ & $385(100 \%)$ & & & \\
\hline \multirow[t]{4}{*}{ Cause } & $\begin{array}{l}\text { Improper } \\
\text { harnessing } \\
\text { and padding }\end{array}$ & $40(10.4 \%)$ & 0 & $77(20 \%)$ & $5(1.3 \%)$ & $6(1.6 \%)$ & $1(0.3 \%)$ & $68(17.7 \%)$ & $198(51.4 \%)$ & 388.278 & 42 & 0.000 \\
\hline & $\begin{array}{l}\text { Overloadi } \\
\text { and working }\end{array}$ & $69(17.9 \%)$ & $2(0.5 \%)$ & $91(23.6 \%)$ & $9(2.3 \%)$ & $11(2.9 \%)$ & $1(0.3 \%)$ & $1(0.3 \%)$ & $184(47.8 \%)$ & & & \\
\hline & Unknown & $1(0.3 \%)$ & $1(0.3 \%)$ & $1(0.3 \%)$ & 0 & 0 & 0 & 0 & $4(0.8 \%)$ & & & \\
\hline & Total & $110(28.6 \%)$ & $3(0.8 \%)$ & $169(43.9 \%)$ & $14(3.6 \%)$ & $17(4.5 \%)$ & $2(0.5 \%)$ & $69(17.9 \%)$ & $385(100 \%)$ & & & \\
\hline
\end{tabular}

Table 3: Type of sore by risk factors.

\begin{tabular}{|c|c|c|c|c|c|c|c|}
\hline \multicolumn{2}{|c|}{ Risk Factors } & \multirow{3}{*}{$\begin{array}{l}\text { Nontreated } \\
180(46.8 \%) \\
\end{array}$} & \multicolumn{2}{|c|}{ Treatment given before survey } & \multirow{3}{*}{$\begin{array}{l}x^{2} \\
1.694\end{array}$} & \multirow{3}{*}{$\begin{array}{l}\text { df } \\
2\end{array}$} & \multirow{3}{*}{$\begin{array}{l}\text { P-value } \\
0.429\end{array}$} \\
\hline & & & \multirow{2}{*}{$\begin{array}{l}\text { Traditional } \\
17(4.4 \%)\end{array}$} & \multirow{2}{*}{$\begin{array}{l}\text { Modern } \\
6(1.6 \%)\end{array}$} & & & \\
\hline Sex & Jenny & & & & & & \\
\hline & Jack & $159(41.3 \%)$ & $13(3.4 \%)$ & $10(2.6 \%)$ & & & \\
\hline & Total & $339(88 \%)$ & $30(7.8 \%)$ & $16(4.2 \%)$ & & & \\
\hline \multirow[t]{4}{*}{ Age } & Young & $2(0.5 \%)$ & 0 & 0 & & & \\
\hline & Adult & $119(30.9 \%)$ & $5(1.3 \%)$ & $3(0.8 \%)$ & 6.184 & 4 & 0.186 \\
\hline & Old & $218(56.6 \%)$ & $25(6.5 \%)$ & $13(3.4 \%)$ & & & \\
\hline & Total & $339(88 \%)$ & $30(7.8 \%)$ & $16(4.2 \%)$ & & & \\
\hline \multirow[t]{4}{*}{ BCS } & Poor & $101(26.2 \%)$ & $14(3.6 \%)$ & $5(1.3 \%)$ & & & \\
\hline & Medium & $195(50.6 \%)$ & $14(3.6 \%)$ & $9(2.3 \%)$ & 3.910 & 4 & 0.418 \\
\hline & Good & $43(11.2 \%)$ & $2(0.5 \%))$ & $2(0.5 \%)$ & & & \\
\hline & Total & $339(88 \%)$ & $30(7.8 \%)$ & $16(4.2 \%)$ & & & \\
\hline \multirow[t]{4}{*}{ Cause } & $\begin{array}{l}\text { Improper harnessing } \\
\text { and padding }\end{array}$ & $174(45.2 \%)$ & $14(3.6 \%)$ & $10(2.6 \%)$ & & & \\
\hline & $\begin{array}{l}\text { Overloading and } \\
\text { working }\end{array}$ & $162(42 \%)$ & $16(4.2 \%)$ & $6(1.6 \%)$ & 10.240 & 14 & 0.74 \\
\hline & Unknown & $3(0.8 \%)$ & 0 & 0 & & & \\
\hline & Total & $339(88 \%)$ & $30(7.8 \%)$ & $16(4.2 \%)$ & & & \\
\hline
\end{tabular}

Table 4: Treatment given before survey of back sore by risk factors.

\section{Discussion}

Degree of back sore was significantly $(\mathrm{P}<0.05)$ varied in donkeys of different sex, cause and age but insignificantly associated $(\mathrm{P}>0.05)$ with body condition score. This is most probably attributed to the fact that the jack usually pass time on work, physically strong and was vulnerable to the heavy loads that result in the sever degree of sore $75(19.5 \%)$ on the back of working jack than Jenny. In this study the mild degree of back sore 215(55.8\%) was higher than the other degree of sore. However, in contrary to this finding Demelash and Moges [12] reported from Hawassa area that 41 (16.1\%) of mild degree of injuries.

Old age donkeys were extremely vulnerable 256 (66.5\%) to the back sore than the rest. Similar findings were reported by Birhan et al. [19] and Demelash and Moges [13]. As age increases the working time and overloading was increasing and donkeys were easily predisposed to back sore.

The medium body condition score donkeys 218 (56.6\%) were frequently exposed to back sore. This study contradicts the findings 
Page 5 of 6

reported by Mekuria et al. [20]; Birhan et al. [17] and Pearson et al. [17] which states that the sore was dominant on poor body condition score donkeys in the study area.

The location of the back sore was significantly associated $(\mathrm{P}<0.05)$ with body conditions but not associated $(\mathrm{P}>0.05)$ with sex, age and cause of the back sore. Frequency of back sore on thoracic $211(54.8 \%)$ was the higher than others and similar study reported proportion of 58 (22.8) was frequently observed on thoracic area than others by Demelash and Moges [13]. It indicates that the thoracic area is mainly susceptible to back sore.

The study indicated that improper harnessing and padding 198 (51.4\%) followed by overloading and overworking 184 (47.8\%) were the most cause of back sore of donkeys in the study area. Lower proportions were reported by Fentie et al. [21] from Bahir Dar states that harnessing 78 (31.2\%) and overloading 31 (12.4\%) and Demelash and Moges [13] from Hawassa area reported that improper harness 66 (26\%) was identified as the major cause of injury in donkeys. This is most probably due to carried materials on the back lower heat exchange and physiologically to overcome the heat donkeys excrete sweat. The excreted sweat moist the hair and skin and carried materials polish with the wetted skin result in damage of the skin as well as underlining muscles based on the type of carried materials and how long donkeys under work.

Type of back sore showed a significant $(\mathrm{P}<0.05)$ variation in donkeys of different sex, age, body condition score and cause of sore. In the study area erosion 169 (43.9\%) was more frequent followed by laceration 110 (28.6\%). Erosion was principally caused by overloading and overworking 91 (23.6\%) followed by improper harnessing and padding 77 (20\%). Hence, during this study in the Ada'a district there was huge harvesting of crops and owners sold cattle dung to Bishoftu town by traveling long distance which increased probability of occurrence of back sore of the study donkeys.

Study presented that there is no variation $(\mathrm{P}>0.05)$ in the treatment offered to donkey of different sex, age, body condition score and cause of sore. Majority of donkeys with back sore 339(88\%) were not presented purposively for treatment of back sore by their owners. This finding is greater than the previous work of Demelash and Moges [13] who reported from Hawassa area that higher number of owners did not provide any treatment (38.6\%) to their equines.

\section{Conclusion and Recommendations}

This study investigated that back sore is the problem of health and welfare of working donkeys in the area. In addition, the study clearly showed that donkeys of all age, sex and body condition score affected by back sore and several causes are responsible for back sore on working donkeys of the study area. Majority of the working donkeys with back sore were untreated for both traditional and modern treatment.

Therefore, Regular and continuous community education about the proper use of harness on their donkeys should be given. Donkeys with the back sore should get sufficient rest. Owners should avoid the overload and overwork of their equine. Finally, further studies should be conducted on the prevalence, economic significance and health and welfare importance of back sore in equine in vast areas of Ethiopia.

\section{Acknowledgment}

I am thankful for financial support from Donkey Health and Welfare Project.

\section{References}

1. FAO (1997) FAO Statistical Database Website. Food and Agriculture Organization, Rome, Italy.

2. FAO (2003) FAO Statistical Database Website. Food and Agriculture Organization, Rome, Italy.

3. Fielding D (1991) the number and distribution of equines in the world. In: Proceedings of the Colloquium on Donkeys, Mules and Horses in Tropical Agricultural development, Edinburgh, Pp: 62-66.

4. Pearson AR, Simalegna ET, Krecek CR (2003) Harnessing and Hitching Donkeys, Mules and horses for work. Centre for Tropical Veterinary Medicine University of Edinburgh, UK, pp: 5.

5. EARO (1999) National Animal Health Research program strategy document. Ethiopian Agricultural Research Organization (EARO), Addis Ababa, Ethiopia, pp: 1-46.

6. Astatke A and Mohammed Saleem MA (1996) Draught animal power for land use intensification in the Ethiopian high lands. World Animal Review 86: 3-11.

7. Gebrewold A, Tegegn A and Yami A (2004) Research needs of donkey utilization in Ethiopia, In: Feilding and Development. A Resource book of the Animal Traction Network for Eastern and Southern Africa (ATNESA), TechnicalCenter for Agriculture and Rural Cooperation (CTA), Wageningen, The Netherlands, pp: 77- 81.

8. Hassen K (2000) A preliminary study on the socio-economic importance, health problems and other management constraints of horses in mid and high land areas of north Gondor. DVM thesis, FVM, AAU, Debre Zeit, Ethiopia.

9. Gizaw (1987) Policy and Strategy Option towards rapid development of the Ethiopia livestock improvement conference, IAR, Ethiopia.

10. Mohammed A (1991) Management and breeding aspects of donkeys around Awassa, Ethiopia. In: Feilding and Pearson RA (Eds) Donkeys, Mules and Horses in Tropical Agricultural Development Pp: 185-188.

11. Svendsen E (1997) Parasites Abroad. The professional hand book of the donkey, (3rdedn) WhittetBooks limited, 18 Anley Road, London, Pp: 166-182.

12. Demelash B and Moges W (2006) Causes and factors Associated with occurrence of external injuries in working Equines in southern Ethiopia. International Journal of Applied Research in Veterinary Medicine 4: 1-7.

13. NMSA (2003) National Metrological service Agency, Addis Ababa, Ethiopia.

14. MoARD (2004) Ministry of Agriculture and Rural Development. Ada'a liben Bureau of Agriculture, Ethiopia.

15. Thrusfield M (1995) Veterinary Epidemiology. (2nd edn) UK, Black well Science Ltd. Pp: 182-183.

16. Crane M (1997) Medical. In: The professional Hand book of the Donkey (3rd edn) Whittet Books limited, 18 Anley Road, London Pp:19-36.

17. Yoseph S, Feseha G and Abebe W (2001) Survey on helminthosis of equines in Wonchi, Ethiopia. Journal of the Ethiopian Veterinary Association 5: 47-61.

18. Svendsen E (1997) Parasites Abroad. The professional hand book of the donkey. (3rd Edn) WhittetBooks limited, 18 Anley Road, London pp: 166-182.

19. BirhanG, Chanie M, Tesfaye T, Kassa A, Mekonnen B et al. (2014) Incidence of Wound and Associated Risk Factors in Working Donkeys in Yilmana Dens District.Global Veterinaria 13: 1

20. Mekuria S, Matusala M, Rahameto A (2013) Management practices and welfare problems encountered on working equids in Hawassa town, Southern Ethiopia. Journal of Veterinary Medicine and Animal Health 5: 243-250. 
Citation: Kassaye BK. (2015) Investigation on Factors Associated with Back Sore in Working Donkeys in Ada'a District, Central Oromia, Ethiopia. J Veterinar Sci Technol 6: 256. doi:10.4172/2157-7579.1000256

Page 6 of 6

21. Fentie G, Teka F, Fikadu A, Tsegalem A, and Ayalew N (2014) Injuries in Donkeys and Mules: Causes, Welfare Problems and Management
Practices in Amhara Region, Northern Ethiopia. Applied Journal of Hygiene 3: 31-37. 